\title{
Best Practices to Increase Manufacturing Productivity - Comparative study
}

\author{
Ion Cosmin Gherghea ${ }^{1, *}$, Constantin Bungau ${ }^{1}$, and Dan Claudiu Negrau ${ }^{2}$ \\ ${ }^{1}$ University of Oradea, Engineering and Management Department, Romania \\ ${ }^{2}$ University of Oradea, Industrial Engineering Department, Romania
}

\begin{abstract}
Nowadays, manufacturing companies are involved in a big competition, each of them looking to increase productivity and profit by implementing best practices within the company. The present paper presents an analysis of best practices of manufacturing companies which contributes to increasing and improving the productivity, and also have been identified new trends regarding best practices implemented in manufacturing companies. In order to accomplish this research, has been analyzed a successful manufacturing company in the field of manufacturing and automation from Romania. To collect data for this study there were accessed two databases, different specialized websites in the field, but the most important source of information was obtained from the analyzed company. One of the best practices identified in this study was to improve the productivity through re-engineering, practice that the company studied has implemented. In order to highlight this good practice, namely reengineering, were analyzed in parallel both of existing manufacturing types from the analyzed company, respectively production on $\mathrm{CNC}$ processing centers and classical production. The exemplification of both types of productions was done by using a Lean Manufacturing method, namely Value Stream Mapping, identifying the operational flow of both types of production.
\end{abstract}

\section{Introduction}

The evolution of technology, increasing the competitiveness of companies and high demand for products and services, both manufacturing and service companies has led to a continuous search for innovative solutions, respectively to the adoption of best practices within the organization, that contributes to increased the customer satisfaction and also to the development of the company. [1].

Regarding manufacturing companies, which are focused on increasing productivity and profit, while seeking to reduce costs and waste from manufacturing process through a proper implementation of best practices. According T. Guidat et all examples of best practice can be found in different fields, both in the service and production sectors, wich can be found in the private and public sectors [2].

* Corresponding author: cosmin.gherghea@ecsud.oradea.ro 
Bjørge Timenes Laugen et all, highlights the fact that best practices are implemented in the top of the manufacturing companies. [3]. In order to continuous improvement of processes. the manufacturing companies implement different production systems and methods for optimization and elimination of waste within the processes. Lean manufacturing is one of the best-known and successful techniques (recognized as one of the best practices in manufacturing companies), that contributes to continuous process improvement by identifying and eliminating losses using Lean-specific manufacturing methods [4]. Lean manufacturing is a production system developed by Toyota, and the main techniques for identifying and eliminating losses (Japanese muda) are Value Stream Mapping, Poka Yoke, 5 S, Single Minute Exchange of Die, Kanban, Just in Time, Pull System, etc [5- 7]. Following research conducted best practices have been identified in the manufacturing companies, which are presented in the figure below.

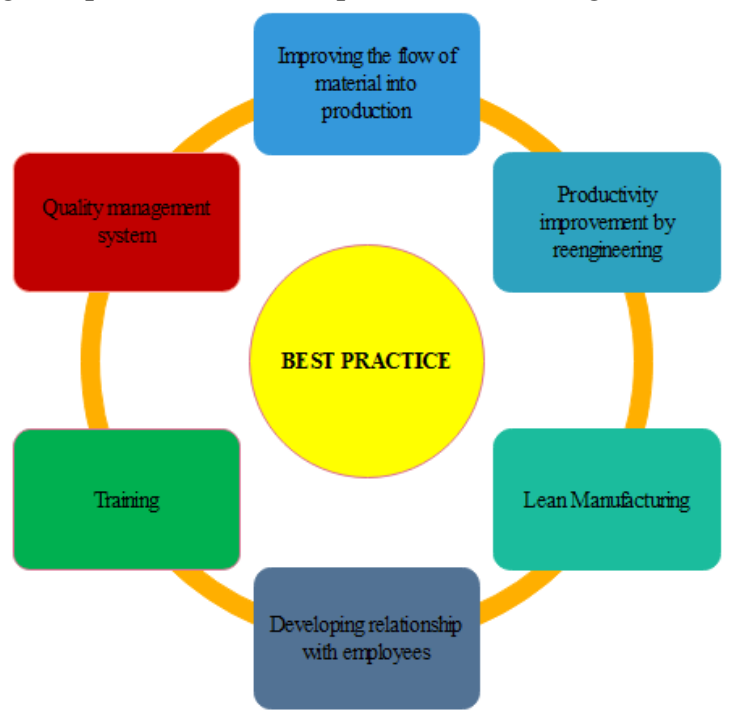

Fig. 1. Best practice from manufacturing companies (own source).

According to the best practices identified, improving productivity through reengineering plays an important role in manufacturing companies, because adopts a number of new technologies, including the introduction of $\mathrm{CNC}$ machining centers in the manufacturing process.

Improving productivity is a continuous challenge for each company. Improving productivity through reengineering involves a number of changes and optimizations in the production process that aims to achieve products that correspond to the customer's expectations in terms of quality and also to eliminate those non-conformities of the product (scrap) that can occur after the technological process, this eliminates certain production costs.

According to Özge Akbaba and Erkut Altındağ, the reengineering concept was introduced in companies together with the development of technology in the early 1990s, increasing company performance by reducing production costs, increasing product quality, reducing production time and reducing product delivery time [8]. The manufacturing companies that have adopted this concept of reengineering, have begun to change their old technologies with the newest and also more advanced ones, so they have acquired $\mathrm{CNC}$ machining centers. According to Abdul Hadi Jalaludin et all, CNC machining centers have been built to increase machining precision, which has a major impact on the final product quality, and have also been built to increase the capacity production [9]. Nowadays, the 
manufacturing industry produces various high complexity pieces due to the use of CNC machining centers and industrial robots, both has an important role in increasing production efficiency and increasing production flexibility [10].

The manufacturing proces of parts that require the machining of complex curved surfaces, the reduction of contour errors has significantly contributed to the performance of CNC machining centers, while the parts are made with high precision and high working speeds, while also ensuring the quality of product surfaces [11]. According to Tufan Ko and Erhan Bozdag, the $\mathrm{CNC}$ machining centers have become the most popular production equipment used in SMEs, especially due to the problem solving in the production, increasing the flexibility of the production and reducing the downtime [12]. The CNC machining centers have come to play an important role in the manufacturing industry due to increased of productivity but also due to increase of quality, aiming at eliminating operational costs, while producing products with a high roughness and a longer life of the tool [13]. According to R. Ramesh et all, in terms of production on CNC machining centers, an automated intelligent manufacturing system was developed to estimate and control surface finishing using support vector machines (SVM) which have contributed significantly to reducing production time (lead time), increasing automation and to control the manufacturing process [14]. Another very important aspect in the operation of CNC machining centers is the energy consumption. Lingling L, et al., in the paper "Influence factors and operational strategies for energy efficiency improvement of CNC machining" shows the prodution on CNC machining centers as the most important activity in the manufacturing industry, underlining that in the United States $31 \%$ of the total energy consumed is destined for this industry [15].

\section{CNC technology analysis}

Both production on $\mathrm{CNC}$ machining centers and classic production using conventional machine tools, have their advantages and disadvantages.

The main advantages and disadvantages of production on $\mathrm{CNC}$ machining centers are presented in the figure below.

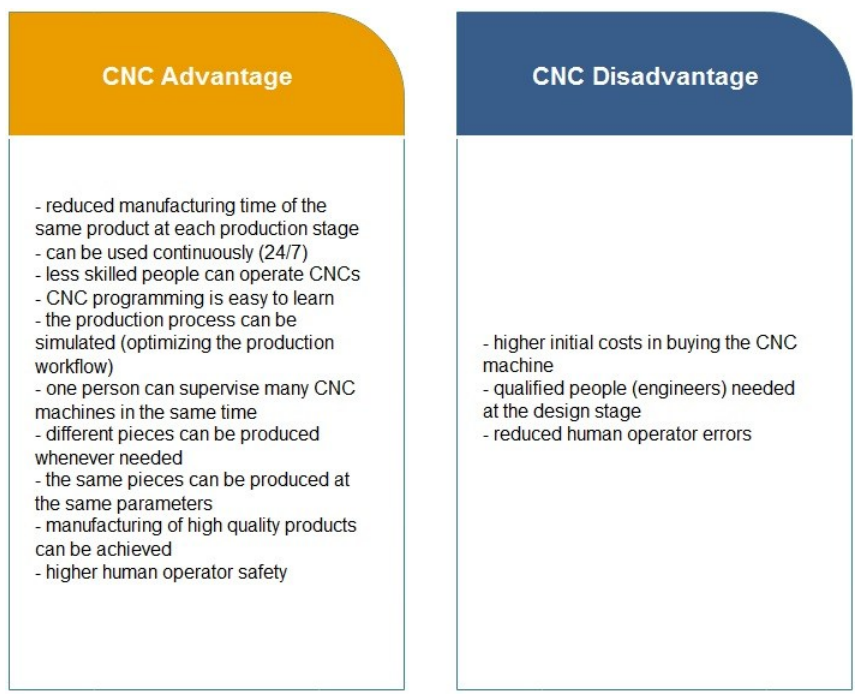

Fig. 2. CNC advantages vs disadvantages (own source). 
The company that undertook this research, currently adopts two methods of launching incoming orders, the first method being the classic one in which each phase is carried out in different working cells, and the second is production on CNC machining center in which most of the operations are carried out to obtain the finished product.

The main reason that the company has adopted production on $\mathrm{CNC}$ machining centers is to obtain high quality products, eliminating certain mistakes caused by certain human errors.

\section{Application of Value Stream Mapping (VSM) - a case study}

In the below figure are presented the execution drawing of a plastic injection nozzle, which was executed on a CNC machining center and classic method of execution using conventional machine tool.

The number of pieces from batch is 100 pieces.
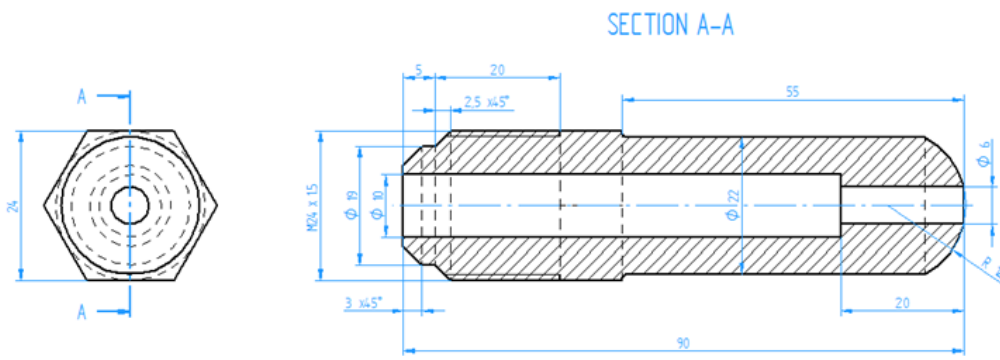

Fig. 3. 2 D plastic injection nozzle view (own source).
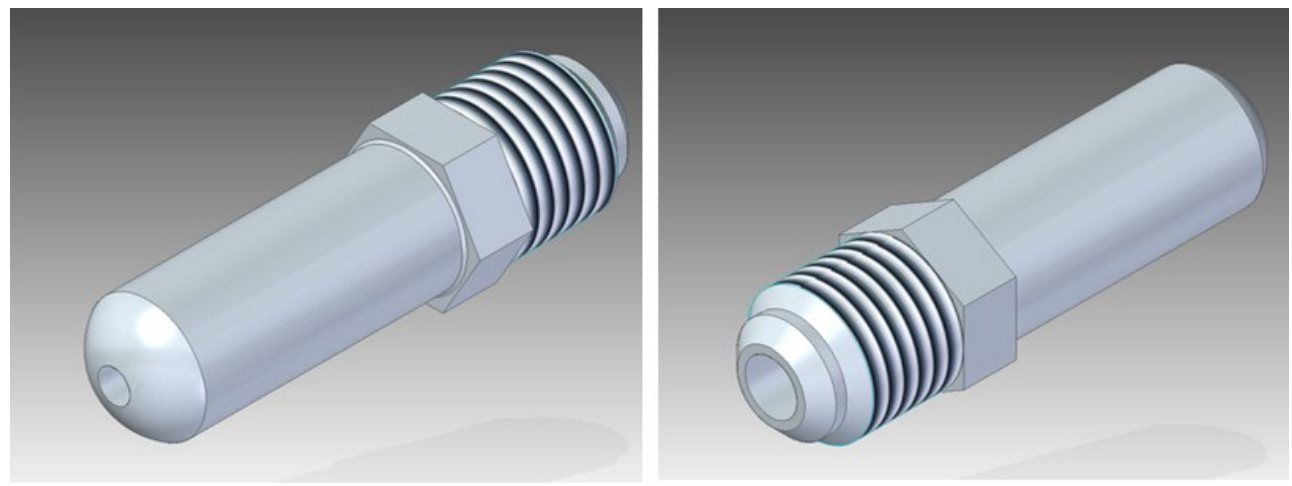

Fig. 4. 3 D plastic injection nozzle view (own source).

In order to get an overview of both production methods analyzed, the VSM was built to exemplifies all of the operations executed, the operational times, but also the downtimes of the production process.

VSM is a Lean manufacturing method that helps to visualize the entire technological process, identifying quickly the existing losses and eliminating them, achieving a continuous flow of raw material in the manufacturing process and eliminating the downtimes and the waiting times within the technological flow. 


\subsection{Classic production}

In order to munufacturing the plastics injection nozzle using the classic production method, will be use hexagon bar 24, X11CrMo5 material with a length of $6000 \mathrm{~mm}$. In order to be processed, the following operations will be performed as shown in Table 1. Considering that the analysis of the manufacturing process is performed for a single piece, both the operational times of the manufacturing process and the thermal treatment of the parts are analyzed for a single the piece (even if in the case of heat treatment the whole 100 pieces are treated once within 2 hours, which represents 72 seconds per piece).

Table 1. The production process of the plastic injection nozzle - classic production.

\begin{tabular}{|c|c|c|c|c|}
\hline $\begin{array}{l}\text { No. } \\
\text { crt }\end{array}$ & Operation & Machinery & $\begin{array}{c}\text { Measuring } \\
\text { device }\end{array}$ & Operations time \\
\hline 1 & Cutting 24x600 & $\begin{array}{c}\text { Band Saw } \\
\text { Machine Pilous } \\
\text { ARG } 300 \text { Plus } \\
\text { S.A.F. }\end{array}$ & Tape measure & $\begin{array}{c}40 \mathrm{~s}-\text { processing } \\
5 \mathrm{~s}-\text { measuring } \\
10 \mathrm{~s}-\text { handling parts }\end{array}$ \\
\hline 2 & $\begin{array}{l}\text { Turning right side: } \\
\text { radius } 12.5 \mathrm{~mm} \\
\text { Diameter } \Phi 22 \\
\mathrm{~L}=55 \mathrm{~mm}\end{array}$ & $\begin{array}{l}\text { SNA } 400 \text { turning } \\
\text { machine }\end{array}$ & $\begin{array}{c}\text { Caliper } \\
\text { Roughness } \\
\text { tester } \\
\text { Radius gages }\end{array}$ & $\begin{array}{c}550 \mathrm{~s}-\text { processing } \\
30 \mathrm{~s}-\text { measuring } \\
115 \mathrm{~s}-\text { handling parts } \\
\text { and time for cutting } \\
\text { tool positioning }\end{array}$ \\
\hline 3 & Cutting at $\mathrm{L}=90 \mathrm{~mm}$ & $\begin{array}{l}\text { SNA } 400 \text { turning } \\
\text { machine }\end{array}$ & Caliper & $\begin{array}{c}20 \mathrm{~s}-\text { processing } \\
5 \mathrm{~s}-\text { measuring } \\
7 \mathrm{~s}-\text { time for cutting } \\
\text { tool positioning }\end{array}$ \\
\hline 4 & $\begin{array}{l}\text { Turning left side: } \\
\text { Diameter } \Phi 24, \Phi 19 \\
\text { Chamfering } 2.5 \times 45^{0} \\
\text { Drilling } \Phi 10, \Phi 6 \\
\text { Filleting M24x1.5 }\end{array}$ & $\begin{array}{l}\text { SNA } 400 \text { turning } \\
\text { machine }\end{array}$ & $\begin{array}{c}\text { Caliper } \\
\text { Metric Thread } \\
\text { Gauges }\end{array}$ & $\begin{array}{c}320 \mathrm{~s}-\text { processing } \\
40 \mathrm{~s}-\text { measuring } \\
90 \mathrm{~s}-\text { polishing with } \\
\text { sandpaper } \\
80 \mathrm{~s}-\text { handling parts } \\
\text { and time for cutting } \\
\text { tool positioning }\end{array}$ \\
\hline 5 & $\begin{array}{l}\text { Thermal treatment - } \\
\text { hardening }\end{array}$ & $\begin{array}{c}\text { Heat treatment } \\
\text { oven }\end{array}$ & hardness tester & $\begin{array}{l}72 \mathrm{~s}-\text { processing } \\
90 \mathrm{~s}-\text { polishing } \\
\text { radius } 12.5 \mathrm{~mm}+ \\
\text { cleaning with wire } \\
\text { brush }\end{array}$ \\
\hline & \multirow{2}{*}{\multicolumn{3}{|c|}{ Total time }} & $\begin{array}{l}\mathbf{1 0 0 2} \mathbf{s} \text { - production } \\
\text { lead time }\end{array}$ \\
\hline & & & & $\begin{array}{c}382 \mathbf{s}- \\
\text { Value added time }\end{array}$ \\
\hline
\end{tabular}

\section{Notifications:}

At second operation, turning right side, will be used 2 types of cutting tools (turn tool

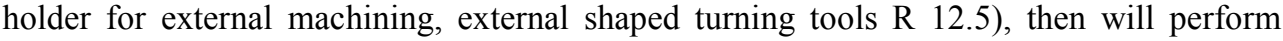
grinding operations to obtain roughness (sandpaper with different grits). At fourth operation, turning left side, will be used the same both cutting tools, only at angles the turn tool holder for external machining should be inclined, will be measured interphase more than once until the indicated odds are obtained.

The thread will be obtained from several passes (will be used external threading turning tool as with $\mathrm{CNC}$ machining centers, but with a much lower cutting speed. 
At classic production each nozzle from the batch (100 pieces) will be measured, while in the case of processing on the $\mathrm{CNC}$ machinig center will be measure the first and possibly another 2 or 3 pieces for checking the wear of the cutting tools, ensuring the quality of the parts executed.

Based on the data from table 1, in which the operations necessary for the execution of the piece were listed, was built the VSM, exemplifying the entire technological process, respectively the operational flow.

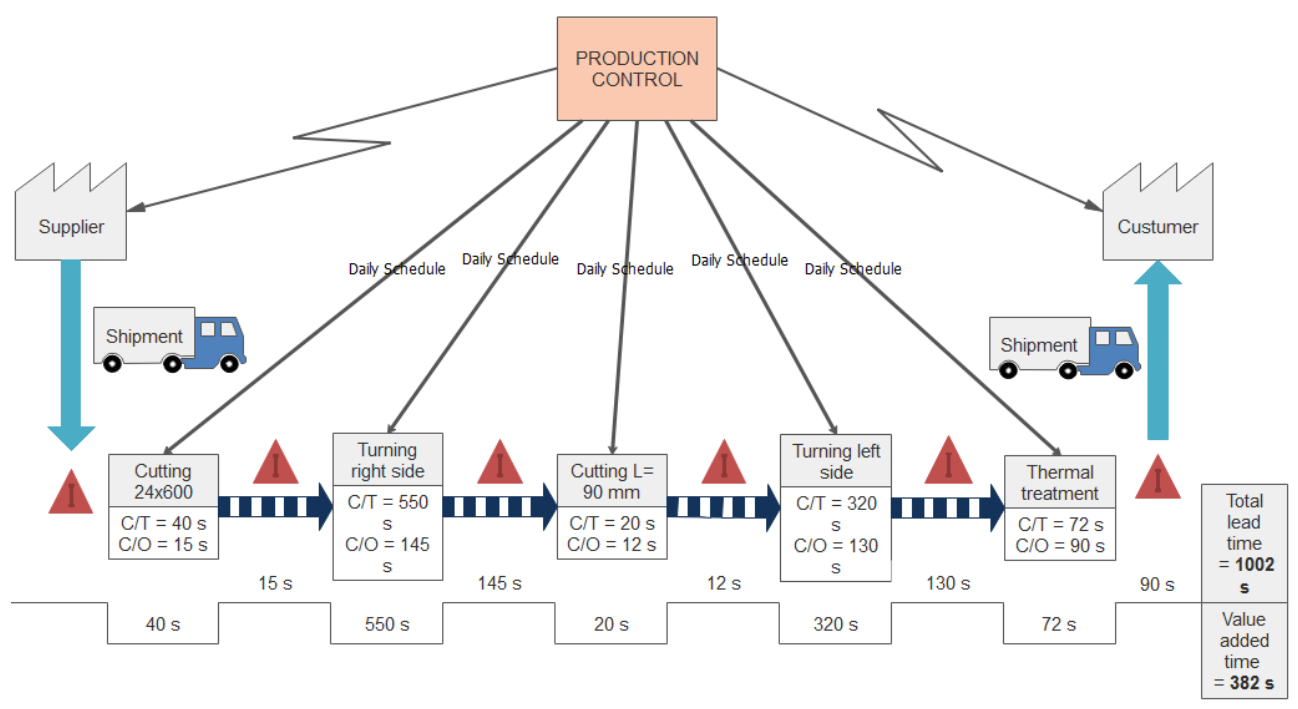

Fig. 5. The VSM of classic production (own source).

\subsection{CNC production}

In order to manufacturing the plastic injection nozzle on the $\mathrm{CNC}$ machining center, in the below table are presented the operations performed during the manufacturing process.

Table 2. The production process of the performed piece - CNC production.

\begin{tabular}{|c|c|c|c|c|}
\hline $\begin{array}{l}\text { No. } \\
\text { crt }\end{array}$ & Operation & Machinery & $\begin{array}{c}\text { Measuring } \\
\text { device }\end{array}$ & Operations time \\
\hline 1 & Cutting 24x600 & $\begin{array}{c}\text { Band Saw Machine } \\
\text { Pilous ARG } 300 \text { Plus } \\
\text { S.A.F. }\end{array}$ & Tape measure & $\begin{array}{c}40 \mathrm{~s}-\text { processing } \\
5 \mathrm{~s}-\text { measuring } \\
10 \mathrm{~s}-\text { handling parts }\end{array}$ \\
\hline 2 & $\begin{array}{c}\text { Turning right } \\
\text { side: radius } 12.5 \\
\text { mm } \\
\text { Diameter } Ф 22 \\
\text { L=55 mm }\end{array}$ & Fanuc 0i-tc & $\begin{array}{c}\text { Caliper } \\
\text { Roughness } \\
\text { tester } \\
\text { Radius gages }\end{array}$ & $\begin{array}{l}120 \mathrm{~s}-\text { processing } \\
30 \mathrm{~s}-\text { measuring } \\
15 \mathrm{~s}-\text { handling parts } \\
\text { and time for cutting } \\
\text { tool positioning }\end{array}$ \\
\hline 3 & $\begin{array}{c}\text { Cutting at } \mathrm{L} \\
\mathrm{mm}\end{array}$ & Fanuc $0 \mathrm{i}$ & Caliper & $\begin{array}{c}15 \mathrm{~s}-\text { processing } \\
5 \mathrm{~s}-\text { measuring } \\
7 \mathrm{~s}-\text { time for cutting } \\
\text { tool positioning }\end{array}$ \\
\hline 4 & $\begin{array}{c}\text { Turning left side: } \\
\text { Diameter } \Phi 24, \\
\Phi 19 \\
\text { Chamfering } \\
\end{array}$ & Fanuc 0i & $\begin{array}{c}\text { Caliper } \\
\text { Metric Thread } \\
\text { Gauges }\end{array}$ & $\begin{array}{l}100 \mathrm{~s} \text { - processing } \\
10 \mathrm{~s}-\text { measuring } \\
30 \mathrm{~s}-\text { handling parts } \\
\text { and time for cutting }\end{array}$ \\
\hline
\end{tabular}




\begin{tabular}{|c|c|c|c|c|}
\hline & $\begin{array}{c}2.5 \times 45^{0} \\
\text { Drilling } \Phi 10, \Phi 6 \\
\text { Filleting M24x1.5 }\end{array}$ & & & tool positioning \\
\hline 5 & $\begin{array}{l}\text { Thermal treatment } \\
\text { - hardening }\end{array}$ & Heat treatment oven & hardness tester & $\begin{array}{c}72 \mathrm{~s}-\text { processing } \\
90 \mathrm{~s}-\text { polishing radius } \\
12.5 \mathrm{~mm}+\text { cleaning } \\
\text { with wire brush }\end{array}$ \\
\hline & & \multirow{2}{*}{\multicolumn{2}{|c|}{ Total time }} & $\begin{array}{c}347 \text { s - Production lead } \\
\text { time }\end{array}$ \\
\hline & & & & $\begin{array}{c}382 \text { s - } \\
\text { Value added time }\end{array}$ \\
\hline
\end{tabular}

Based on the data from table 2, in which the operations necessary for the execution of the piece were listed, was built the VSM, exemplifying the entire technological process, respectively the operational flow.

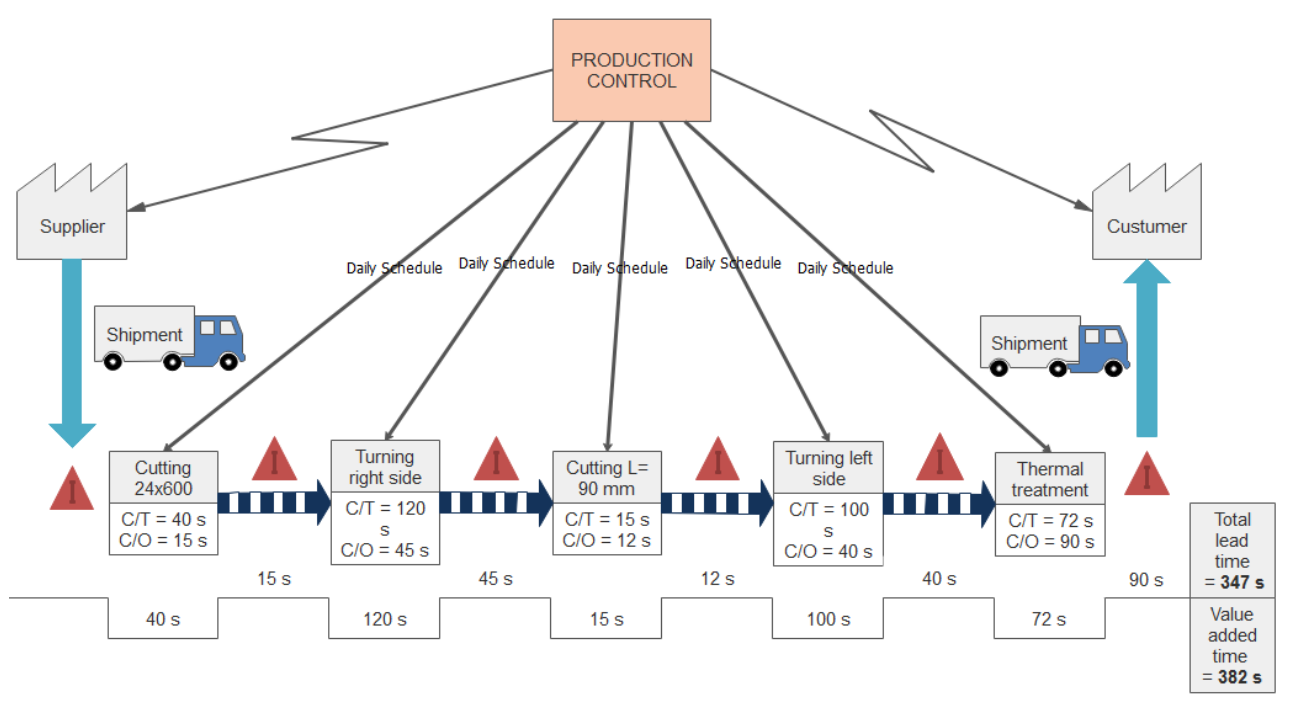

Fig. 6. The VSM of CNC machine (own source).

\section{Results and discussions of case study}

Based on the information from table 1 and 2, and also from both VSM based on the information in the two, the value-creating activities and those that do not create value have been identified.

In the case of classical production, by realizing VSM, the 5 operations in the production process of the performed piece were identified.

The total manufacturing cycle time is 1384 seconds for a single piece, of which the profitable time (value-added time) is 382 seconds, representing $27.6 \%$ of the entire manufacturing cycle, and $72.4 \%$ representing the non-value added time, which in the Lean production are identified as waste (muda in japanese).

In the case of production on CNC machining center, by realizing VSM, the 5 operations in the production process of the performed piece were identified. 
The total manufacturing cycle time for a single piece is 729 seconds, of which the profitable time (value creation activities) is 382 seconds, which represents $52.40 \%$ of the entire production cycle, and $47,60 \%$ representing non-value activities.

The fundamental purpose of Lean production is to eliminate those activities that do not create value, which will lead to lead time reduction.

After analyzing the both production methods, can be observe the benefits of production on the CNC machining center, respectively increasing productivity by reducing lead time and increasing the percentage of activities that create value in the analyzed manufacturing cycle (according to the diagram below).

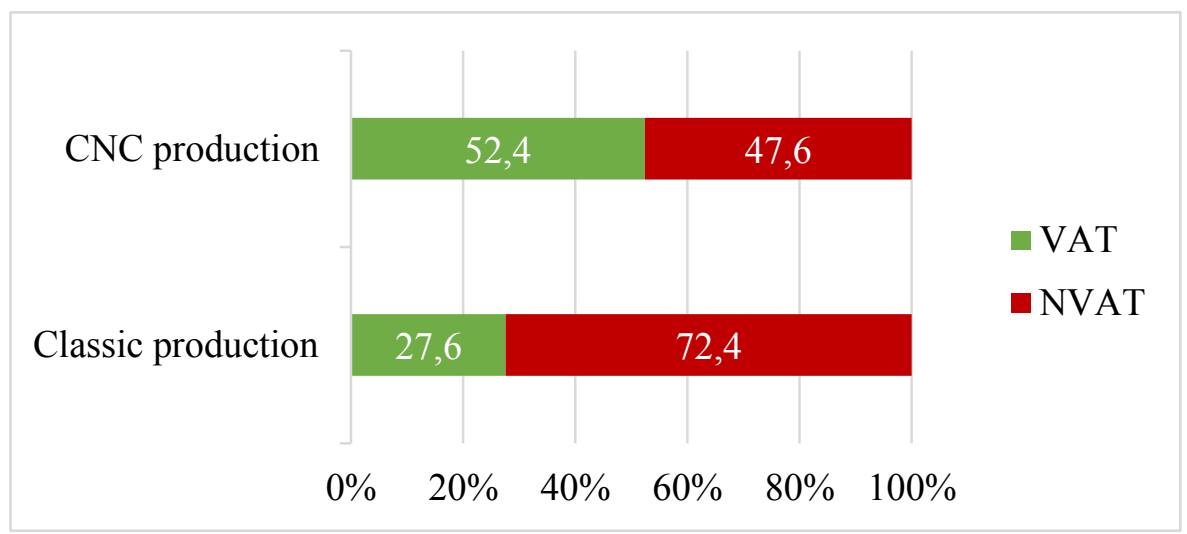

Fig. 7. VAT from classic production versus CNC production (own source). Where: VAT - value added time; NVAT - non value added time

\section{Conclusion}

According to the obtained results, by applying the $\mathrm{CNC}$ machining centers production, the productivity increased by $24.8 \%$ compared to the application of the classical production method.

To produce 100 pieces in the case of classic production, 138400 seconds are required, respectively 38.44 hours without interfering with some additional changes in the manufacturing process. To produce 100 pieces in the case of CNC machining center production, 72900 seconds are required, respectively 20.25 hours without interfering with some additional changes in the manufacturing process.

Therefore, to produce 100 pieces on CNC machining center production, has decreased the production time by 18.19 hours, respectively increasing the productive efficiency by $89.82 \%$ more than the classic production.

Increasing productive efficiency using CNC processing centers has a significant impact on both investment costs and the investment return (break even), wich is significantly higher.

Reengineering has proven to be one of the best practices for increasing manufacturing productivity because it adopts new technologies that contribute significantly to reduce the production costs and production time, while increasing the productivity and the profit.

\section{References}

1. I. Alhuraish, C. Robledo, and A. Kobi, J. Clean. Prod, 64, 325-337 (2017)

2. T. Guidat, J. Seidel, H. Kohl, and G. Seliger, Procedia CIRP, 61, 177-182 (2017) 
3. B. T. Laugen, N. Acur, H. Boer, and J. Frick, Int. J. Oper. Prod. Manag, 25, 2, 131-150 (2005)

4. Bungau C., Blaga F., Gherghea I. C., RMEE, 2, 36-47 (2011)

5. C. Bungau, I. C. Gherghea, and M. Prichici, RMEE, 1, 188-198 (2010)

6. C. Bungau, M. Groza, T. Buidos, I. C. Gherghea, Proceedings of Conference: International scientific assembly ES-NBE 2011 Economic Science in Function of Creating a New Business Environment, 64, 667-679 (2011)

7. I. C. Gherghea, C. Bungau, Proceedings of the 6th Review of Management and Economic Engineering International Management Conference, 6, 564-571 (2018).

8. Ö. Akbaba and E. Altındağ, Procedia - Soc. Behav. Sci., 235, 320-331 (2016)

9. A. H. Jalaludin et al., Int. J. Adv. Manuf. Technol. 93, 1347-1356 (2017)

10. Y. J. Wang, Z. Dong, and G. W. Vickers, Int. J. Adv. Manuf. Technol., 33, 368-378 (2007)

11. J. Ma, F. Wang, D. Song, W. Liu, and Z. Jia, Int. J. Mach. Tools Manuf., 125, 34-54 (2017)

12. T. Koc and E. Bozdag, Int. J. Adv. Manuf. Technol., 34, 1144-1152 (2007)

13. T. S. Lan and M. Y. Wang, Int. J. Adv. Manuf. Technol., 41, 820-826 (2009)

14. R. Ramesh, K. S. Ravi Kumar, and G. Anil, Int. J. Adv. Manuf. Technol., 42, 1103-1117 (2009)

15. L. Li, C. Li, Y. Tang, and Q. Yi, J. Clean. Prod., 161, 220-238 (2017) 